\title{
Ultrafiltration in the Ontario Dairy Industry
}

\author{
Wayne H. Howard ${ }^{1}$ and Remy Lambert ${ }^{2}$ \\ ${ }^{1}$ Associate professor, Department of Agricultural Economics and Business, \\ University of Guelph, Guelph, Ontario. \\ ${ }^{2}$ Assistant professor, Department d'économie rural, \\ Université Laval, Québec, Québec.
}

The economics of introducing ultrafiltration (UF) into the Ontario dairy industry is analyzed. First, a partial budget is developed to determine feasibility of UF on the farm. The budget indicates that the great majority of Ontario dairy farms are not large enough to capture the economies of size inherent in the new technology. Second, a location-allocation model is used to determine the feasibility, number and location of UF collection centers in Ontario. The model indicates that the UF centers would capture the economies of size and the centers would benefit the dairy industry as a whole. However, processors of soft products and consumers of hard products could be worse off because of market changes caused by the UF centers.

Les auteurs examinent les aspects économiques de l'adoption de l'ultrafiltration (UF) dans l'industrie laitière en Ontario. En premier lieu, un budget partiel est établi pour déterminer la faisabilité de l'UF à la ferme. Il appert que la grande majorité des fermes laitières de la province ne sont pas assez grandes pour tirer parti des économies d'échelle inhérentes à la nouvelle technologie. Dans une deuxième étape, un modèle d'implantation est utilisé pour examiner l'emplacement et le nombre éventuels des centres de collecte pour UF en Ontario, ainsi que la faisabilité économique de leur installation. Le modèle montre que les centres de collecte seraient en mesure de tirer avantage des économies d'échelle et qu'en plus ils profiteraient à l'industrie laitière toute entière. Toutefois, les transformateurs de produits frais (fromage cottage, crème glacée, yogourt) et les consommateurs de produits fermes (fromages à pâte ferme, poudre de lait) se trouveraient désavantagés par les bouleversements du marché causés par l'implantation des centres UF.

\section{INTRODUCTION}

Ultrafiltration (UF) is a pressure-driven membrane process for separating the fractional components of milk. It is an advanced form of concentration similar to the old form of cream separation and water extraction by heat evaporation. With UF, the separation is performed through a porous membrane that permits the passage of low-molecular-weight substances. Larger molecules cannot pass through the membrane and are retained. The first component, called permeate, contains waters and lactose, and can have a significant economic value as a source of energy for animal feed. The second component, called retentate, contains milk fat and proteins, as well as a portion of water and lactose. These milk solids are the desirable components in the production of some dairy products, such as cheese. Ultrafiltered milk can also be thermalized (heated) in order to inactivate bacteria growth, which thus allows for longer storage of the concentrated milk, while keeping the milk's desirable quality for cheese making (Besnard, Maubois and Tarek 1981). 
concentration factor, reduce costs of heating and cooling milk, and lower the amount of rennet used in cheese making. Moreover, UF can offer significant advantages in the manufacture of most soft and specialty cheeses, as well as other fermented milk products such as yogurt. Preliminary results are that cheese made from UF milk is not distinguishable from regular-milk cheese (Zall 1987). Consumers have not been shown to reject UF milk products, and there are no regulations restricting their sale. However, regulations and consumer resistance make it doubtful that fluid milk reconstituted from UF milk will be marketed in Canada in the near future.

Although UF technology was first developed for use at the processing plant, a commercial UF system has been developed to concentrate milk on the farm. According to the manufacturer, this system can easily be operated by an average dairy producer. Thus, whether UF is a profitable new technology has to be evaluated both on the farm and at the plant.

This paper evaluates the potential impact of UF technology on the Ontario dairy industry. Specific objectives are to:

- evaluate the profitability of on-farm UF,

- determine the potential for reducing transportation costs through milk collection/UF centers, and

- estimate the welfare impacts of UF on producers, processors and consumers. Results from this study will aid industry and government decision makers in assessing the adoption of UF technology.

\section{THE ONTARIO DAIRY INDUSTRY}

The Ontario dairy industry is highly regulated. All commercial fluid milk sold in Ontario is marketed under a quota system administered by the Ontario Milk Marketing Board (OMMB), which is empowered by the federal and provincial governments. In effect, the OMMB owns quota, which it leases to dairy farmers. Shipping more than one's quota results in a heavy fine. Farmers may trade quota on an auction market, but the
OMMB limits the amount of quota any one producer may have. In addition to quota policies, the OMMB sets prices received for fluid milk and allocates shipments to processors for both fluid and industrial milk.

Industrial milk in Canada is also marketed under quota, which is administered by the Canadian Dairy Commission (CDC). The $\mathrm{CDC}$ and provincial supply management authorities jointly administer the National Market Sharing Quota Plan (MSQ), which allocates the share of Canadian industrial milk among the provinces and establishes a target rate of return for industrial milk and cream. The provinces then manage the MSQ within their jurisdictions. The CDC sets floor prices for butter and skim milk powder through its "offer to purchase" program. The CDC disposes of stocks of nonfat solids on the international markets and recovers any losses through a producer-financed levy.

All fluid and industrial milk haulage and direction in Ontario is controlled by the OMMB. Transporters work for the OMMB rather than for the producer as in the United States, and transport costs are considered a cost of production. Producers pay a pooled transportation cost on a per-hectolitre basis, not a per-hectolitre per-kilometre basis. In 1989 , transport costs averaged $\$ 1.86 / \mathrm{hL}$. The OMMB allocates shipments to processors according to plant quota and end use. Fluid milk has first priority in allocation and receives the highest price. Milk for processed dairy products has five classes of milk for pricing purposes, but effectively consists of two categories: "soft" products, such as cottage cheeses, ice cream and yogurt, and "hard" products, such as hard cheeses and milk powder (OMMB Dairy Statistical Handbook 1987-88). The OMMB allocates milk for soft products on a demand basis, maintaining a price difference between the milk for soft and hard products. Residual milk is then allocated to plants on a historical-use basis to be used for hard products. The price for the residual milk is essentially the CDC support price. Plant supply quota for residual milk can be transferred among plants with the agreement of the OMMB. 
Ontario dairy producers receive a pooled price for their milk based upon their quotas of fluid and industrial milk. Fluid milk prices are set by the OMMB based upon a cost-ofproduction formula. For a readjustment in the milk pricing formula to occur, a change has to be at least $2 \%$ of the total cost of production (Stonehouse 1979; Hamm 1986).

\section{METHODS}

The three specific objectives of this study require three methods of analysis:

- a partial budget to determine the costs and returns of on-farm UF,

- a location-allocation model to determine the optimum number, size and locations of the UF centers, and

- a welfare analysis to estimate the impact of the new technology on dairy producers, processors and consumers.

\section{Partial Budget of On-Farm UF}

Previous studies of on-farm UF reported significant economies of size attributable to the fixed costs of installing a UF system (Slack, Amundson and Hill 1982; Floriot and Overney 1984; Bertrand 1986; Mortara 1986; Zall 1987; Novakovic and Alexander 1987). These studies reported that the savings in costs were not enough to compensate for the cost of installing the UF system in herds of fewer than 100 cows. All the studies used a partial budget approach to compare the costs and returns from UF.

A partial budget calculates the expected change in profit for a proposed change in a farm operation. There are four elements to a partial budget:

- new costs incurred,

- current costs reduced,

- new revenues gained, and

- current revenues lost (Kay 1986).

Given that no UF system is operating on an Ontario dairy farm, a partial budget is computed based upon information from AlfaLaval, the Ontario Dairy Farm Accounting Project (ODFAP), the Ontario Farm Management Accounting Project (OFMAP) and previous studies. The system evaluated is the
Alfa-Laval Thermicon ${ }^{\mathrm{TM}}$ system, which is capable of filtering 75 to 100 litres per hour per membrane to a concentration factor of $2 x$. The partial budget in this study computes:

- amortized installation costs and variable operating costs of the UF system,

- lowered milk cooling and transportation costs resulting from the UF, and

- savings in feed costs by feeding the permeate.

Details of the budget are in the Appendix.

\section{Collection Centers}

Given the distances that some northern Ontario producers ship their milk, it may be feasible to introduce the UF technology in a collection center, where raw milk is brought from several nearby farms, concentrated using UF, and then shipped to final processing plants. In effect, this pooling of milk would allow producers to take advantage of the economies of size indicated by previous studies. There are legal restrictions on marketing fluid milk that has been reconstituted from UF milk. Hence, UF milk from these collection centers would be used for processed dairy products only. Given that $58 \%$ and $75 \%$ of the milk in Ontario and Quebec, respectively, was used as other than fluid, UF centers may be economically feasible in the Canadian dairy industry (OMMB 1989a). The feasibility of UF collection centers has not previously been studied, but such collection centers have been incorporated into other agricultural systems (e.g., Baldwin, Babiker and Larson 1987).

To evaluate the feasibility of UF collection centers, both the number of centers and their locations must be considered. Thus, a location-allocation model is developed that determines the number of concentration centers as well as the locations of those centers. Moreover, the capacity of the centers is varied to determine how the number and location of the centers change as capacity changes.

The literature on location theory is derived from only a few major works (Norman 1979). Weber (1929) is the basis for most of the literature on least-cost theory of location. 
Applications of Weber's theory have included determining optimum plant location in both homogenous and heterogeneous market areas, where demand can be either evenly distributed throughout the area or concentrated at a given point (Losch 1954; Stollsteimer 1963). Usually, supply sources and market territories are defined as predetermined sets of feasible plant locations, transportation and handling cost functions are known, and the optimum or least-cost site is selected from the predetermined feasible set. Thus, the optimization is one of selecting the least-cost site. Alternatively, given a finite set of supply and demand points, there is (are) an optimum location(s) for locating plants. This latter approach generates an optimum site or sites, but still from a predetermined feasible set.

An extension of the site-selecting and site-generating models is to include the cost of establishing a plant in the model, often termed a "fixed-charge problem." Suppose there are $i$ possible locations from which to choose. The cost of establishing and operating a plant producing $S_{i}$ units is $C_{i}\left(S_{i}\right)$ :

$$
\begin{array}{cc}
C_{i}\left(S_{i}\right)=0 & \text { for } S_{i}=0 \\
C_{i}\left(S_{i}\right)=F_{i}+g_{i}\left(S_{i}\right) & \text { for } S_{i}>0
\end{array}
$$

where

$$
F_{i}=\text { the investment or cost of establishing }
$$
the plant and

$g_{i}=$ a unit cost of production at that plant. Models of this type can be used to determine whether a plant should be built as well as its optimal location and optimal size or capacity.

The above models transfer product from the supplier to the consumer; they do not allow for the possibility of transshipping a commodity. A model that allows for transshipment between origins and destinations and also permits storage and processing activities can be used to evaluate the organization of existing plants, as well as the construction of new plants and/or partial processing centers (e.g., Baldwin, Babiker and Larson 1987). Such a model is central to the objectives of this study.

\section{Location-Allocation of Centers in Ontario}

A location-allocation transshipment model is developed to determine the optimal location, number and capacity of UF centers that should be built in Ontario. Recall that the OMMB controls haulage and direction of all milk shipments and that the producers pay pooled transport costs. Hence, the objective of the model is to minimize the cost of shipping milk from the farm to a processing plant, either directly or via a UF center, as illustrated in Figure 1 . The model includes the total quantities of industrial milk supplied and demanded by region, information on transportation costs, the annual amortized cost of establishing UF centers of various capacities and the operating costs of the centers.

Algebraically, the model is:

$$
\begin{aligned}
\operatorname{Min} W & =\sum_{i j} \sum X r_{i j}\left(T_{i j}+C_{j}+F_{j}\right) \\
& +\sum_{j k} X u_{j k}\left(T_{j k}+P u_{k}\right) \\
& +\sum_{i k} \sum_{k} X r_{i k}\left(T_{i k}+P r_{k}\right)
\end{aligned}
$$

such that:

$$
\begin{gathered}
\sum_{i} X r_{i j}=c \sum_{k} X u_{j k} \quad \forall j \\
\sum_{i} X r_{i j}+\sum_{k} X r_{i k} \leq S I i \quad \forall i \\
\sum_{i} X r_{i k}+\sum_{j}^{\sum X} v_{j k} \geq P D I k \quad \forall k \\
\sum_{j} X r_{i j} \leq C A P * N j \quad \forall j
\end{gathered}
$$

The variable definitions are in Table 1 . The objective function has three parts:

- the amortized annual cost of establishing a UF center, $F_{j}$, with capacity $X r_{i j}$ at location $j$ and the cost of transporting raw milk from producer at $i$ to center $j$, $T_{i j}$, and concentrating that milk, $C_{j}$,

- the cost of transporting UF milk from center $j$ to the processing plant $k, T_{j k}$, and the cost of processing UF milk, $P u_{k}$, and 


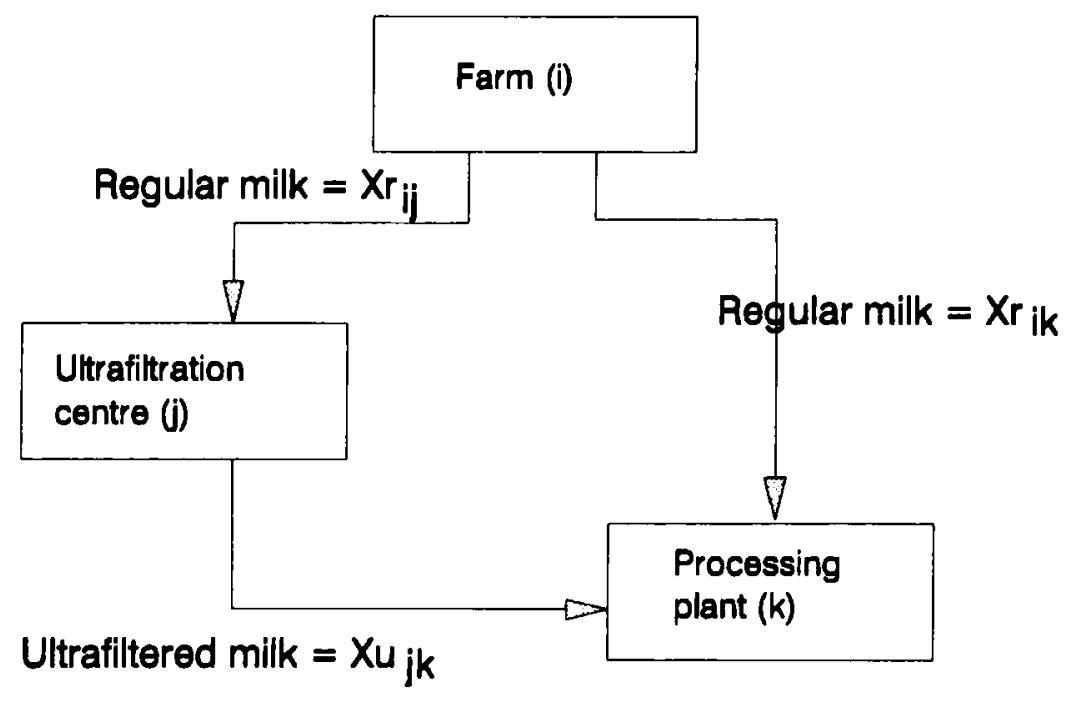

Figure 1. Alternative routes with UF center

Table 1. Definition of variables used in location-allocation model

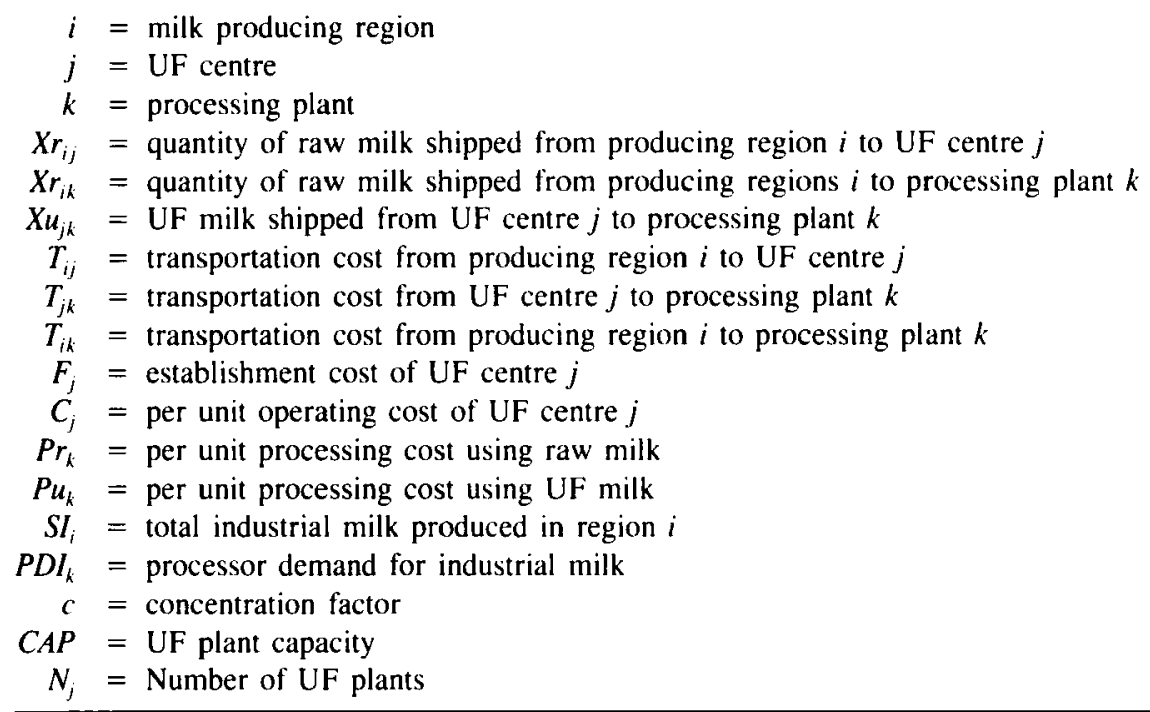

- the cost of transporting raw milk directly from the producer at $i$ to the processing plant $k, T_{i k}$, and processing raw milk, $\mathrm{Pr}_{k}$.

The objective function ensures that the cost of establishing a UF center is not incurred unless raw milk is shipped to that center. Moreover, establishment and operating costs are a function of the amount of milk to be shipped through the UF center; i.e., $F_{j}=$ $f\left(X r_{i j}\right)$ and $C_{j}=h\left(X r_{i j}\right)$. Hence, the objective function jointly determines whether or not 
the UF center should be built as well as its location and size.

The model was constrained to ensure that:

- the amount of UF milk shipped, $X \boldsymbol{u}_{j k}$, is not more than the equivalent concentrated amount of raw milk received, $X r_{i j} / c$ (Eq. 2),

- total milk shipped from producing region $i$ to a UF center, $X r_{i j}$, and/or directly to a processing plant, $X r_{i k}$, is not more than is produced in region $i$, $S I_{i}$ (Eq. 3),

- demand in region $k, P D I_{k}$ is satisfied (Eq. 4),

- the total UF capacity, $C A P * N_{j}$, is not less than the amount of milk filtered (Eq. 5), and

- standard nonnegativity conditions apply.

Costs of establishing and operating a UF center increase with the capacity of the center, which is a function of the quantity of milk to be filtered. The UF systems considered for the centers are larger than those considered on the farm; hence the establishment and operating costs are estimated from a limited number of existing commercial systems and engineering information. Alfa-Laval had $10 \mathrm{hL} /$ hour and $70 \mathrm{hL} /$ hour systems for $\$ 75,000$ and $\$ 370,000$, respectively, in 1989 . These systems could operate a maximum of 12 hours per day due to maintenance and cleaning requirements. Assuming a concave cost function, a linear approximation of the cost of the UF equipment is:

$$
\begin{gathered}
\log (C)=2.522147-0.1656621 * \\
\log (h L / Y)
\end{gathered}
$$

where

$$
C=\text { the cost of the system, and }
$$

$h L / Y=$ the annual capacity in hectolitres. The cost of a building for the system also increases with capacity. Given the space requirements provided by Alfa-Laval, commercial construction companies provide estimates of building costs as:

$$
\begin{aligned}
\log (B C)= & 12.30986-0.9231627 * \\
& \log (h L / Y)
\end{aligned}
$$

where $B C=$ building costs. A one-acre parcel is assumed to accommodate several different building sizes. Land is a small fraction of the total cost of the UF center; hence changes in land size are not considered crucial to the final results. The average cost of a one-acre industrial site in Guelph, Ontario, is used as the basis for land cost. Residential but not commercial property transactions are monitored by the Ontario Real Estate Board. The relationship between residential and commercial land in Guelph is assumed constant for the province and is adjusted regionally.

Operating costs are extrapolated from Novakovic and Alexander (1987) as well as from information provided by Alfa-Laval:

$$
\begin{aligned}
\log (O C / h L)= & 3.868828-0.4897507 * \\
& \log (h L / Y)
\end{aligned}
$$

where $O C=$ operating costs. Straight-line depreciation is assumed, with life expectancies of 10 and 20 years on the UF equipment and building, respectively, and zero salvage value. The Bank of Canada average bond yield of $9.9409 \%$ is assumed to be the opportunity cost of capital.

Transportation costs are modeled as firstdegree approximations of concave functions, with costs a linear function of the distances over which milk is hauled, plus a constant loading cost. Following Flemming and Hamm (1988), transportation costs are differentiated between short (less than 160 kilometres) and long hauls (more than 160 kilometres). Adjusting for inflation and exchange rate differences, Hahn's (1983) model provides a short-haul model based on a truck with 11,400 kilograms of capacity, and Lough (1977) provides a long-haul model based on a truck with 21,590 kilograms of capacity. The short- and long-haul cost functions are, respectively:

$$
\begin{aligned}
& \text { Short-haul cost }(\$ / \mathrm{hL})=0.4658 \\
& +0.0112 * \text { distance in kilometres }
\end{aligned}
$$

Long-haul cost $(\$ / \mathrm{hL})=0.4607+$ $0.0080 *$ distance in kilometres 
Road distances between cities in Ontario average approximately $30 \%$ longer than the straight-line distance between the cities (Morris, Wesolowsky and Love 1988). Hence, transportation distances are estimated at $130 \%$ of a straight-line distance between cities.

The processors' demand for industrial milk is effectively two demands: milk for soft products and milk for hard products. The total quantity demanded may not be more than a processor's quota for industrial milk (MSQ) plus milk transferred from the fluid market. Hence, any change in processors' demand for one class of milk affects their total demand for milk. A synthetic model is employed to approximate processors' demand for milk. Details of the model are in the next section.

Adjusting for inflation, it cost approximately $\$ 18.23$ to process a hectolitre of milk into cheese in 1989 (Statistics Canada 1986). Estimates of savings due to using UF milk have ranged from $\$ 0.33 / \mathrm{hL}$ to $\$ 3.51 / \mathrm{hL}$, depending on the manufacturing method used and the effect of UF on cheese yield. A conservative, realistic estimate of $\$ 0.90 / \mathrm{hL}$ is used in this study (Novakovic and Alexander 1987; Hill 1989).

Quantities of milk supplied and processed by region are supplied by the OMMB. Synthetic functions using quantities from the $\mathrm{OMMB}$ and elasticity estimates from prior studies are generated for the processors demand for milk and are discussed in the next section.

\section{UF Technology and Industry Welfare}

In order to determine the net welfare effects of UF technology on the Ontario dairy industry, a synthetic model is developed that incorporates two major changes expected from UF. First, UF is expected to change transportation cost, which is considered a cost of production under the supply management system in Ontario. In 1989, transportation costs averaged $3.45 \%$ of the cost of production; e.g., $\$ 1.64 / \mathrm{hL}$ in southern Ontario. For a readjustment in the milk pricing formula to occur, a change has to be at least $2 \%$ of the total cost of production. This $2 \%$ limit means that UF has to decrease transportation costs by at least $\$ 0.95 / \mathrm{hL}$ in southern Ontario $(57 \%$ of the transportation cost) to affect the milk pricing formula. Second, UF is expected to reduce the cost of processing dairy products, especially the "soft" processed products; it costs less to process UF milk than regular milk into soft dairy products (Novakovic and Alexander 1987). Hence, the derived demand for milk for soft products is likely to change with the introduction of UF. However, these changes would occur within the regulated supply management system of the Ontario dairy industry.

Recall that the total supply of milk available for processing is regulated by the OMMB, which sells quotas to dairy farmers for marketing fluid milk (FMQ) and manufactured milk (MSQ). Milk supply to the processor for both soft and hard products is also regulated. Processors can buy milk for soft products on demand, but there is a plant supply quota for milk for hard products. In effect, milk residual to the milk demand for soft products is a perfectly inelastic supply of milk for hard products.

This situation is pictured in Figure 2, where $S s$ and $S h$ are the supplies of milk for soft and hard products, respectively, and $D s$ and $D h$ are the demands for soft and hard products. The supply of milk for hard products, $S h$, is a residual supply:

$$
S h=M S Q+\% F M Q-S s^{*}
$$

where

$$
\begin{aligned}
\% F M Q= & \text { a portion of fluid milk not sold } \\
& \text { as fluid, and } \\
S s= & \text { an amount predetermined from } \\
& \text { the demand for milk for soft } \\
& \text { products. }
\end{aligned}
$$

Hence, any change in $S s$ will affect $S h$.

Figure 2 can also depict the final market for soft and hard products. Given $S s$ and $D s$, consumer surplus is area $a$ and producer (processor) surplus is area $b+c$ (Figure 2a). Consumer and producer surplus for hard products given residual supply, $S h$, and consumer demand, $D h$, are areas $f+g+h$ 


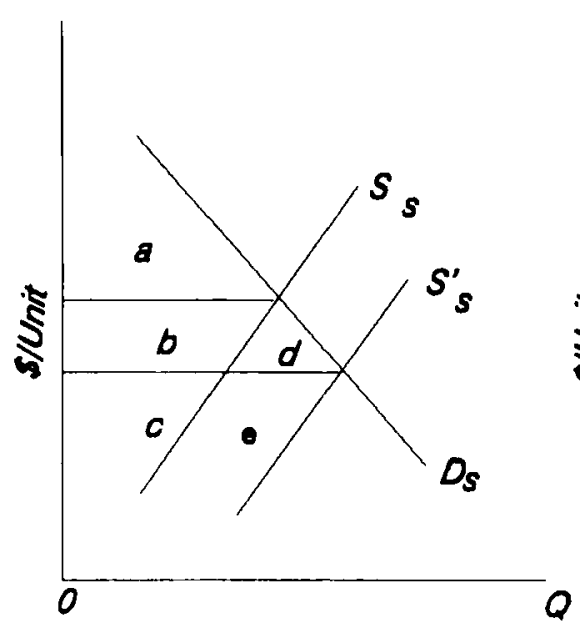

Figure 2.a Soft Products

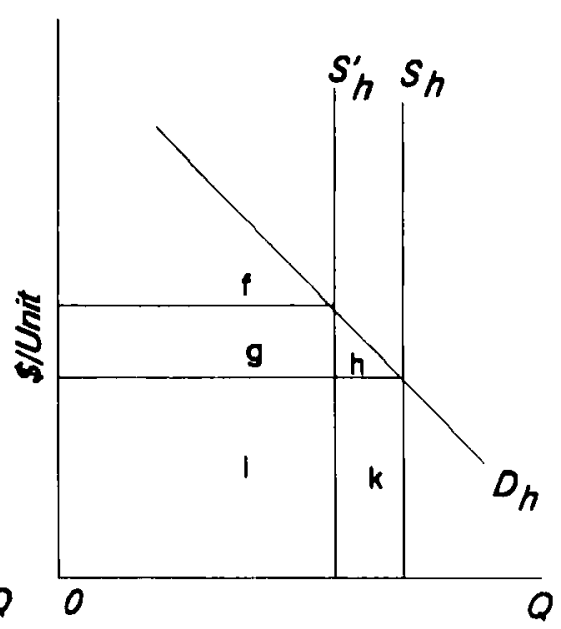

Figure 2.b Hard Products

Figure 2. Demand and supply of milk for "soft" and "hard" dairy products

and $i+k$, respectively (Just, Hueth and Schmitz 1982). Assuming that UF lowers the cost of soft products, i.e., shifts the supply from $S s$ to $S s^{\prime}$, consumers' welfare would increase by area $b+d$, while soft products processors' welfare would change to area $c+e$. If area $e-b>0(<0)$, processors would be better (worse) off. The increased demand for milk for soft products would result in a decrease in the supply of milk available for hard products. Subsequently, supply of hard products would shift from $S h$ to $S h^{\prime}$. Consumers' surplus for hard products would decrease to area $f$, and hard products processors' welfare would change to area $g+i$. Processors would be better (worse) off if area $g>k(g<k)$.

Dairy farmers' welfare would also be affected by UF. Transportation costs are part of the farmer's cost of production under the supply management system in Ontario. Figure 3 depicts the Ontario milk market before UF with supply, $S$, demand, $D$, and an effective quota, $Q s$, which is less than the market equilibrium quantity without the quota. The producer's surplus is area $e+f$, while area $d$ is the rental rate of quota. With the introduction of UF, farm supply shifts to
$S^{\prime}$ due to a decrease in production costs. Farmer's surplus will change to area $f+g$, and the rental rate for quota will increase to area $d+e+h$. Hence, introduction of UF will increase the economic rents accruing to dairy quota.

A synthetic model is required to determine the magnitudes of net welfare changes due to the introduction of UF:

$$
\begin{gathered}
P D_{s p}=a_{0}+a_{1} * M P_{s p}+a_{2} * P_{s p}+a_{3} * P_{w} \\
C D_{s p}=c_{0}+c_{1} * P_{s p p} \\
C D_{h p}=d_{0}+d_{1} * P_{h p} \\
C D_{s p}=P S_{s p} \\
C D_{h p}=P S_{l l p} \\
S I=P D I=P D_{s p}+P D_{h p}
\end{gathered}
$$




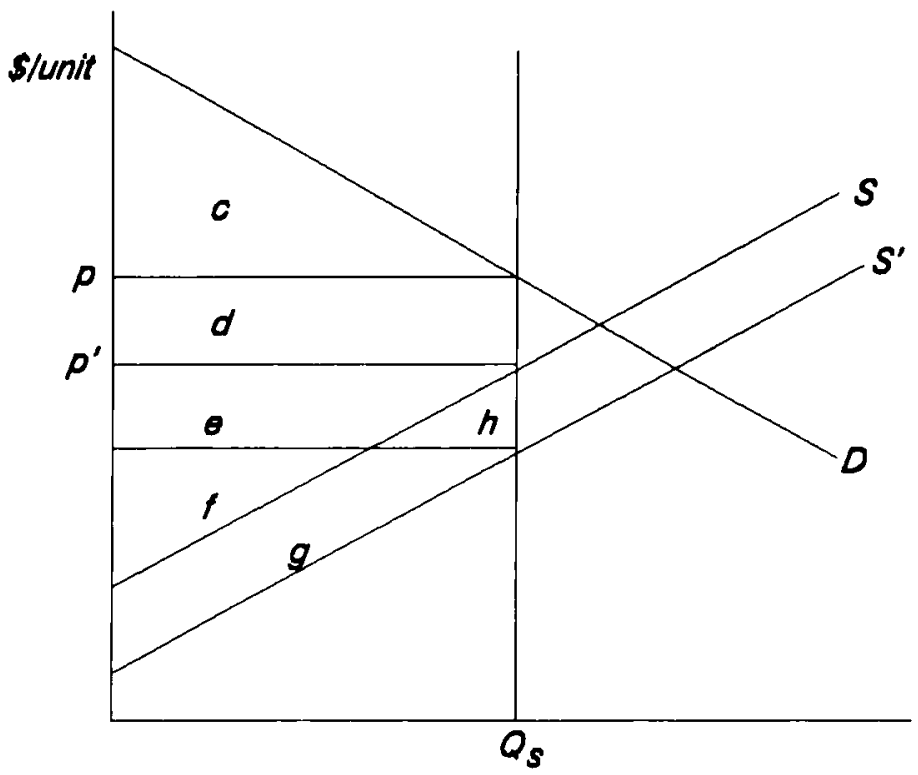

Figure 3. Supply, demand and production quota at the farm level

where

$$
\begin{aligned}
P D_{s p} \text { and } P D_{h p}= & \text { processor demand for } \\
& \text { milk for soft and hard } \\
& \text { products, respectively, } \\
M P_{s p}= & \text { processor price for } \\
& \text { milk for soft products, } \\
P_{s p} \text { and } P_{h p}= & \text { wholesale prices of } \\
& \text { soft and hard products, } \\
& \text { respectively, } \\
P_{n}= & \text { weighted processor } \\
& \text { input price, excluding } \\
& \text { milk, } \\
C D_{s p} \text { and } C D_{h p}= & \text { consumer demand for } \\
& \text { soft and hard products, } \\
& \text { respectively, } \\
P S_{s p} \text { and } P S_{h p}= & \text { processor supply of } \\
& \text { soft and hard products, } \\
S I= & \text { the supply of industrial } \\
& \text { milk, and }
\end{aligned}
$$

Eqs. 10,11 and 12 are equilibrium conditions required to obtain a solution from the model. Elasticities used to derive the coefficients and starting values used to calibrate the model are in Table 2.
Table 2. Elasticities (E) and values used to calibrate synthetic model

Elasticities $^{\text {a }}$

$\begin{array}{llr}E_{a 1} & =-0.21 \\ E_{a 2} & =0.30 \\ E_{d 3} & =-0.50 \\ E_{c 1} & =-0.54 \\ E_{d 1} & =-1.00\end{array}$

1989 values to calibrate synthetic model ${ }^{\mathrm{h}}$

$P D_{s p} \quad=2,103,090 \mathrm{hL}$

$M P_{s p} \quad=\$ 45.1633 / \mathrm{hL}$

$P_{s p} \quad=\$ 4.079 / \mathrm{kg}$

$P_{h p} \quad=\$ 9.008 / \mathrm{kg}$

$P_{w} \quad=\$ 18.23 / \mathrm{hL}$

$C D_{h p} \quad=686.908(1000 \mathrm{~kg})$

$C D_{\mathrm{s} p} \quad=1,049,034(1000 \mathrm{~kg})$

aSource: Goddard and Conboy (1989).

'Source: OMMB (1989a, 1989b, 1991); Statistics Canada. 
Table 4. Minimum profitable herd size with a $20 \%$ decrease and increase in selected variables

\begin{tabular}{lcr}
\hline & \multicolumn{2}{c}{$\begin{array}{c}\text { Minimum profitable } \\
\text { herd size }\end{array}$} \\
\cline { 2 - 3 } & $20 \%$ & $20 \%$ \\
Modified variable & decrease & increase \\
\hline Basic case & 112 & 112 \\
Transportation cost & 127 & 88 \\
Interest rate & 99 & 119 \\
Equipment cost & 86 & 127 \\
Production level & 128 & 83 \\
Concentration factor & 140 & 86 \\
Milking time & 116 & 99 \\
Electricity cost & 111 & 113 \\
Labor cost & 103 & 117 \\
All variables & 155 & 79 \\
\hline
\end{tabular}

\section{RESULTS}

\section{Partial Budgets}

The results of the partial budgets for herds ranging from 30 to 150 cows are reported in Table 3. The savings in costs from the UF, including the value of the permeate fed on farm, do not appear to offset the amortized installation and operating costs for herds of fewer than 130 cows. A search finds the minimum herd size for a positive net return to be 112 cows. Arbitrarily increasing/decreasing the budget variables by $20 \%$ gives a minimum herd size ranging from 79 to 155 cows, as reported in Table 4. Moreover, a breakeven analysis determines that the annual investment cost of the UF system evaluated in this study would have to decrease to $\$ 1631$ from $\$ 4719$ in order for the UF system to be profitable on a 50-cow dairy farm. Given that Ontario's average herd size is 49 cows and that only $4.5 \%$ of the herds are larger than 80 cows (OMMB 1989a), it is unlikely that many Ontario dairy producers will adopt on-farm UF systems, given the present cost of the systems. 


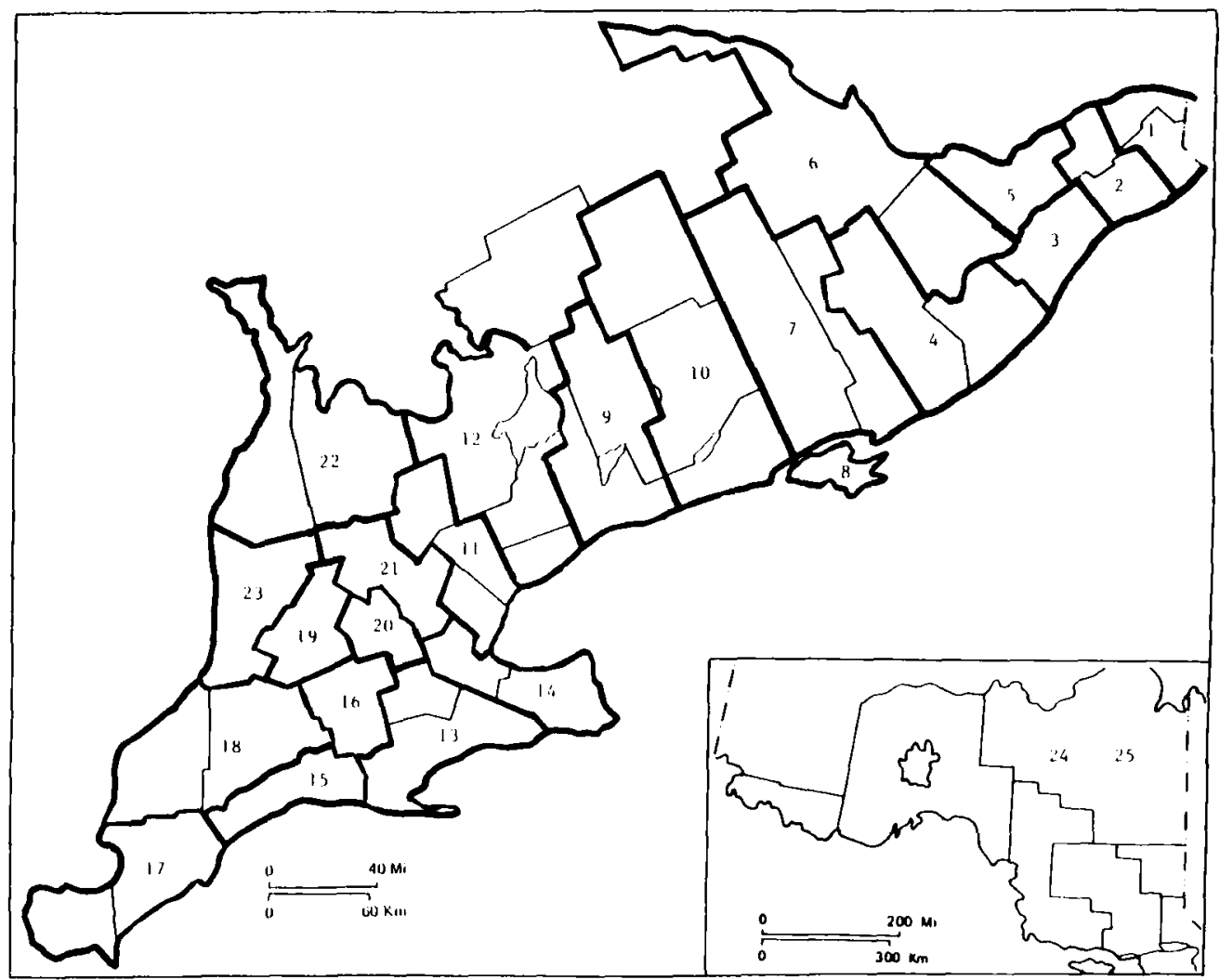

Figure 4. Twenty-five milk-producing regions in Ontario

\section{Collection Centers}

A location-allocation model based on Eqs. 1 to 5 is run to determine the optimum number and location of UF collection centers in Ontario. Ontario's 53 counties are aggregated into the 25 producing regions for computational tractability. ${ }^{2}$ Milk production is assumed to be in the center of a county, with the center of production in each of the 25 production regions a weighted average of milk production location. The 11 demand regions correspond to the $12 \mathrm{OMMB}$ regions, with regions 10 and 11 combined because of the few processors in those regions. The regions are delineated in Figures 4 and 5.

Given that the objective function determines the location, size and decision on whether or not to build a UF center, the objective function is nonlinear. The processors' demand for milk (Eq. 4) is also nonlinear. Readily available software is unable to do a mixed-integer program with a nonlinear objective function and a nonlinear constraint. Following a standard procedure, the model is optimized, first allowing all variables to be continuous. The model is then rerun with the number of UF centers constrained to 0 or 1 , depending on which is closest. The result is in effect a mixed-integer solution. However, for nonlinear models, this method does not guarantee an optimal solution; none of the solutions near the original (noninteger) solution may meet the integer solution (Leibman et al 1986).

A reference solution determines that $13,853,780 \mathrm{hL}$ of milk are shipped from 


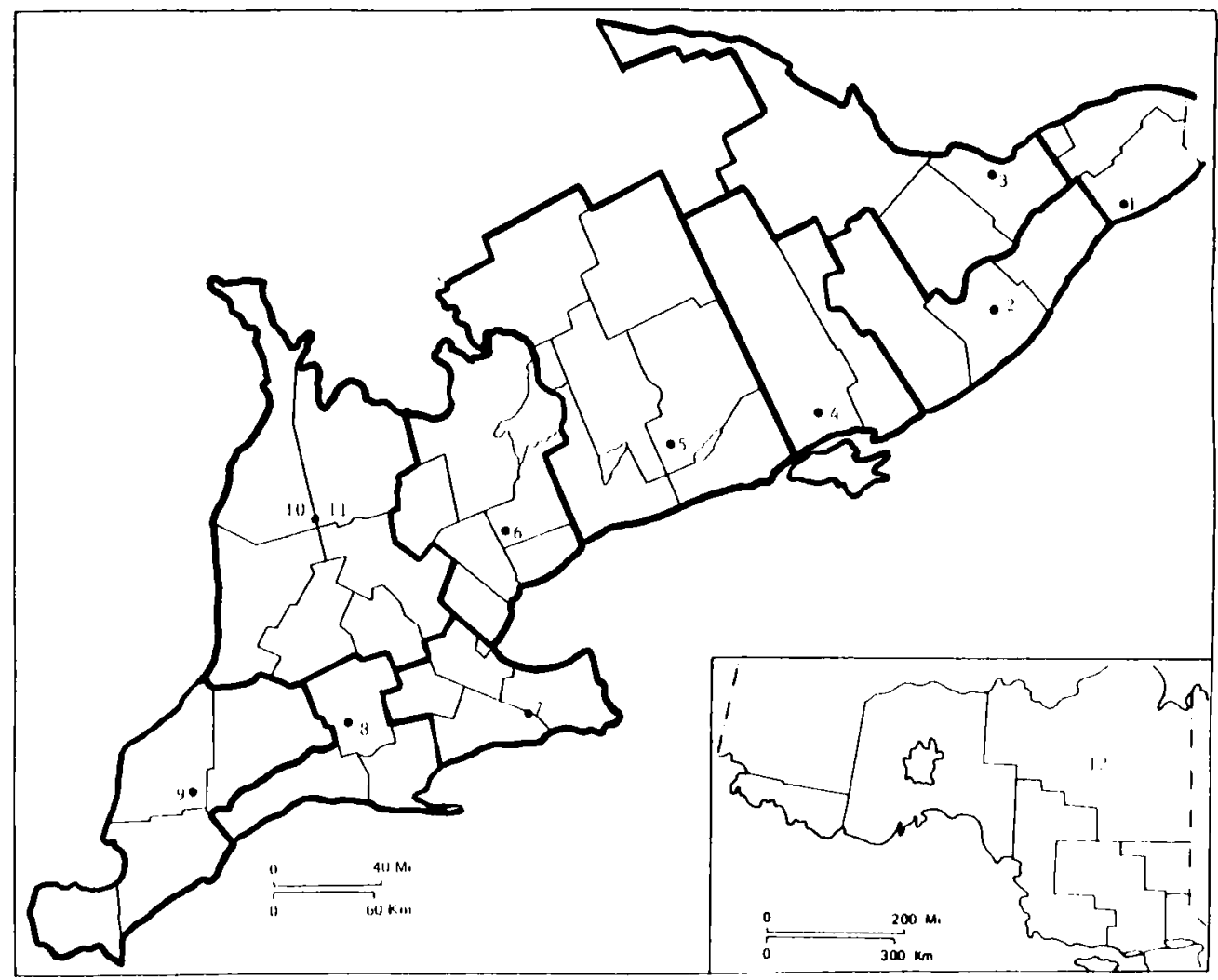

Figure 5. Eleven milk demand regions in Ontario

farms to plants at a cost of $\$ 2.14 / \mathrm{hL}$, as reported in Table 5 . This cost is $15 \%$ higher than the 1989 official transportation cost of $\$ 1.86 / \mathrm{hL}$ (OMMB 1989b). The introduction of $100 \mathrm{~L}$ /hour UF collection centers would decrease transportation costs by almost $10 \%$, to $\$ 26.7$ million from $\$ 29.6$ million, as reported in Table 5. Average transportation costs would decrease to $\$ 1.93 / \mathrm{hL}$ from $\$ 2.14 / \mathrm{hL}$. All 25 producing regions would adopt the technology and there would be no changes in the trade flows between regions. Given that transport costs are pooled and paid by farmers in Ontario, it is expected that changes in transportation costs due to the introduction of UF would be passed on to farmers. Moreover, transport costs are considered a cost of production (COP) and are included in the COP formula used to determine the price of milk. A COP change of $2 \%$ or more will trigger a change in the price of milk. Given that there can be a delay in implementing changes to the COP formula, the model is run with and without a milk price change. However, as reported in Table 5 . whether or not the change in transport costs due to UF triggers a change in the price of milk, the price of soft dairy products would decrease slightly, while the price of hard products would increase slightly. A change in the price of milk makes the changes in prices of soft and hard products only slightly greater.

\section{Welfare Effects of UF}

Even with a milk price adjustment due to lower transportation costs, dairy farmers" 
Table 5. Changes in prices and quantities demanded due to UF technology with $100 \mathrm{hL} /$ hour collection centres

\begin{tabular}{lccc}
\hline \multicolumn{1}{c}{ Variable } & Reference & \multicolumn{2}{c}{ With UF } \\
\cline { 3 - 4 } & solution & $\begin{array}{c}\text { No price } \\
\text { change }\end{array}$ & $\begin{array}{c}\text { Price } \\
\text { change }\end{array}$ \\
\hline Total transportation costs & $\$ 29.647 .089$ & $\$ 26.737 .795$ & $\$ 26,737,795$ \\
Average transportation cost $(\$ / \mathrm{hL})$ & $\$ 2.14$ & $\$ 1.93$ & $\$ 1.93$ \\
Quantity demanded $(1000 \mathrm{~kg}):$ & & & \\
$\quad$ Soft products & 686,908 & 697,808 & 698,240 \\
Hard products & $1,049,035$ & $1,046,056$ & $1.045,938$ \\
Price of: & & & \\
Milk for soft products $(\$ / \mathrm{hL})$ & 45.1633 & 45.1633 & 44.9533 \\
Milk for hard products $(\$ / \mathrm{hL})$ & 41.9324 & 41.9324 & 41.7224 \\
Soft products $(\$ / 1000 / \mathrm{kg})$ & 4079.00 & 3959.14 & 3954.39 \\
Hard products $(\$ / 1000 / \mathrm{kg})$ & 9008.08 & 9033.22 & 9034.23 \\
\hline
\end{tabular}

welfare would increase with the introduction of UF, as reported in Table 6. Processors of soft products would be worse off, as would consumers of hard products, while processors of hard products and consumers of soft products would be better off. Overall, there would be a net benefit to the industry.

The results are relatively stable. Costs are arbitrarily increased $20 \%$, both individual costs and all costs, to see how the agents' welfare change as costs change. For example, given a $20 \%$ rise in all costs, producers' welfare is positive, but $38 \%$ lower than in the initial solution, as reported in Table 6 . Industry surplus decreases by only $13 \%$ with a $20 \%$ increase in all costs.

The collection centers proposed in the model have varying capacities, depending on supply and demand factors at their location. However, as with many new technologies, the first UF plants will likely be smaller than optimum and operating on a trial basis. In such a scenario, it is important to determine optimum locations for these "trial plants." A capacity constraint is added to the model to see which regions would adopt UF given different plant capacities, and how adoption of these smaller plants would affect the agents' and the industry's welfare.
Table 6. Agents' and industry surplus after the introduction of $100 \mathrm{~L} /$ hour UF collection centres under base scenario and with $20 \%$ increase in various costs $\mathbf{( \$ 0 0 0 )}$

\begin{tabular}{lcc}
\hline Agent & Base & $20 \%$ in all costs \\
\hline Producers & $+2,909$ & +1.909 \\
Processors & & \\
$\quad$ Soft & $-40,515$ & $-39,374$ \\
$\quad$ Hard & $+14,533$ & $+12,008$ \\
Consumers & & \\
$\quad$ Soft & $+86,305$ & +82.989 \\
$\quad$ Hard & $-27,384$ & -26.327 \\
Industry & $+35,848$ & $+31,205$ \\
\hline
\end{tabular}

Fewer regions would find UF collection centers economical as the capacity of the centers decreases. Small centers capable of filtering only $10 \mathrm{hL} /$ hour would be economically feasible in only six regions (Table 7). Also, as the capacity decreases, the total surplus to the industry decreases (Table 8 ). Producers have positive welfare changes with the introduction of UF with no capacity constraints, but under constraints their welfare 
Table 7. Producing regions adopting ultrafiltration under different plant capacity

\begin{tabular}{|c|c|c|c|c|c|c|c|c|}
\hline \multirow[b]{2}{*}{ Region } & \multirow{2}{*}{$\begin{array}{c}\text { No } \\
\text { capacity } \\
\text { constraint }\end{array}$} & \multicolumn{7}{|c|}{ Size (in $h L / h$ ) } \\
\hline & & 100 & 80 & 60 & 40 & 30 & 20 & 10 \\
\hline 1 & $y$ & $y$ & $y$ & $y$ & $\mathrm{y}$ & no & no & no \\
\hline 2 & $y$ & $y$ & $y$ & $y$ & $y$ & no & no & no \\
\hline 3 & $y$ & $y$ & $y$ & $y$ & $y$ & $y$ & no & no \\
\hline 4 & $y$ & $y$ & $y$ & $\mathrm{y}$ & $y$ & no & no & no \\
\hline 5 & $y$ & $y$ & $y$ & $\mathrm{y}$ & $\mathrm{y}$ & no & no & no \\
\hline 6 & $y$ & $y$ & $y$ & $y$ & $y$ & $y$ & $y$ & no \\
\hline 7 & $y$ & $y$ & $y$ & $\mathrm{y}$ & no & $y$ & $y$ & no \\
\hline 8 & $y$ & $y$ & $y$ & $y$ & $\mathrm{y}$ & no & no & no \\
\hline 9 & $y$ & $y$ & $y$ & $y$ & $\mathrm{y}$ & $y$ & $y$ & no \\
\hline 10 & $y$ & $y$ & $y$ & $y$ & $y$ & $y$ & no & no \\
\hline 11 & $y$ & $y$ & $y$ & $y$ & $y$ & $y$ & no & no \\
\hline 12 & $y$ & $y$ & $y$ & $y$ & $y$ & $y$ & $y$ & $y$ \\
\hline 13 & $y$ & $y$ & $y$ & $y$ & $y$ & $y$ & no & no \\
\hline 14 & $y$ & $y$ & $y$ & $y$ & $y$ & no & no & no \\
\hline 15 & $y$ & $y$ & $y$ & $y$ & $y$ & $y$ & no & no \\
\hline 16 & $y$ & $y$ & $y$ & $y$ & $y$ & $y$ & $y$ & $y$ \\
\hline 17 & $y$ & $y$ & $y$ & $y$ & $y$ & $y$ & $y$ & $y$ \\
\hline 18 & $y$ & $y$ & $y$ & $y$ & $y$ & no & no & no \\
\hline 19 & $y$ & $y$ & $y$ & $y$ & $y$ & $y$ & no & no \\
\hline 20 & $y$ & $y$ & $y$ & $y$ & $y$ & $y$ & no & no \\
\hline 22 & $y$ & $y$ & $y$ & $y$ & $y$ & $y$ & $y$ & $y$ \\
\hline 23 & $y$ & $y$ & $y$ & $y$ & $y$ & $y$ & $y$ & $y$ \\
\hline 24 & $y$ & $y$ & $y$ & $y$ & $y$ & $y$ & $y$ & no \\
\hline 25 & $y$ & $y$ & $y$ & $y$ & $y$ & $y$ & $y$ & $y$ \\
\hline
\end{tabular}

y: adopted

no: not adopted

Table 8. Welfare impact of introducing ultrafiltration into different capacity plants $(\$ 000)$

\begin{tabular}{lcccccc}
\hline & \multicolumn{7}{c}{$\mathrm{hL} / \mathrm{h}$} \\
\cline { 2 - 7 } & 80 & 60 & 40 & 30 & 20 & 10 \\
\hline Change in producers' surplus: & +139 & $-1,108$ & $-2,909$ & -139 & +831 & -416 \\
Change in processors' surplus & & & & & & \\
$\quad$ Soft products & $-39,374$ & $-38,671$ & $-36,416$ & $-21,788$ & $-11,750$ & $-6,725$ \\
$\quad$ Hard products & $+11,998$ & $+2,322$ & $+11,055$ & $+6,500$ & $+3,300$ & $+1,758$ \\
Change in consumers' surplus & & & & & & \\
$\quad$ Soft products & $+82,989$ & $+81,524$ & $+76,880$ & $+46,403$ & $+25,177$ & $+14,483$ \\
$\quad$ Hard products & $-26,327$ & $-16,436$ & $-24,371$ & $-14,572$ & $-7,709$ & $-4,239$ \\
Total industry surplus change & $+29,425$ & $+27,630$ & $+24,238$ & $+16,405$ & $+9,848$ & $+4,860$ \\
\hline
\end{tabular}


change is positive under only two scenarios. However, even with a $10 \mathrm{hL} /$ hour plant, there appears to be enough net benefit to the industry for some type of arrangement to compensate the losers in a trial run.

\section{SUMMARY AND CONCLUSION}

As expected, based on previous research, on-farm UF is currently not viable for the Ontario dairy industry. Fewer than $5 \%$ of the herds in Ontario are large enough to take advantage of the economies of size associated with the technology. However, these same economies of size indicate that collection centers may be a viable way to adopt UF in Ontario.

The location-allocation model and the synthetic industry model indicate that UF collection centers may be beneficial for the industry as a whole, but that some agents will gain while others lose. These results are relatively stable even with $20 \%$ cost increases. Previous studies have suggested that the gainers, usually the processors, could compensate the losers, usually the producers. This study, however, reports that producers will gain as long as the UF collection centers are large enough to exploit the economies of size of the technology. The primary losers from UF are processors of soft products. However, the large, positive gains for soft product consumers indicate that there is much room to adjust margins and for change in the industry's structure once UF is introduced.

Lastly, even though definite economies of size are indicated throughout the study, there are industry gains from smaller capacity plants that can be built on a trial basis. This study identifies six regions in Ontario that could likely benefit from small UF collection centers.

\section{NOTES}

'A Journal reviewer questioned whether modeling supply as perfectly inelastic is realistic. The supply is not inelastic throughout its range of production but, in the range in which we are interested, it is very inelastic. Producers do not plan to produce milk used in hard products; they produce for fluid milk and for soft products, which receives a higher price than does milk used in hard products. The milk used for hard products is a residual of the quantity supplied for other uses. Hence, in the price ranges we model, the quantity of milk supplied for hard products is not responsive to price, and an inelastic supply is a reasonable approximation.

${ }^{2} \mathrm{~A}$ Journal reviewer pointed out that aggregating the regions increases the likelihood that the aggregated solution is different from the disaggregated solution. However, the aggregation was necessary given computer limitations; i.e., the model would not converge with 53 regions, but would with 25 regions. It is hoped that the given solution is not too divergent from the disaggregated solution.

\section{ACKNOWLEDGMENT}

This research was funded in part by the Ontario Ministry of Agriculture and Food. The authors wish to acknowledge Art Hill, without whom this research could not have been done, and three anonymous Journal reviewers, whose advice and comments contributed to this paper. All remaining errors are the responsibility of the authors.

\section{REFERENCES}

Alfa-Laval. 1989. Personal communication. Montreal, Quebec.

Baldwin, Dean E., Babiker I. Babiker and Donald W. Larson. 1987. Spatial organization of marketing facilities in developing countries: A case of oilseeds in Sudan. Agricultural Economics, 1: 209-227.

Bertrand, F. 1986. L'optimisation de la collecte du lait : aspects techniques et economiques. Thèse de doctorat. Paris : Grignon, Institut National Agronomique.

Besnard, S., J. L. Maubois and A. Tarek. 1981. Ultrafiltration : thermalisation du lait à la production : aspects bacteriologiques. Le lait 61: 435. Church, D. C. 1986. Livestock Feeds and Feeding. 2nd ed. Englewood Cliffs, N.J.: Prentice-Hall.

Christaller, W. 1933. Die Zentralen Orte in Suddeutschland. Jena.

Flemming, A. M. and L. G. Hamm. 1988. An economic analysis of reverse osmosis filtration for interregional milk marketing. Agricultural Economics Report 515. East Lansing: Michigan State University, Department of Agricultural Economics. 
Floriot, J. L. and V. Overney. 1984. Faisabilité industrielle de la transformation retentat : Emmental. Lorraine, France : Institut National Polytechnique, Department Génie des systèmes industriels.

Glover, F. A. 1985. Ultrafiltration and reverse osmosis for the dairy industry. Publication 5. Reading, U.K.: National Institute for Research in Dairying.

Goddard, E. W. and P. W. Conboy. 1989. The relationship between monetary policy and quota values of the supply managed dairy industry. Guelph: University of Guelph, Department of Agricultural Economics and Business.

Hamm, L. G. 1986. The Canadian quota system: An analysis and comparison of the Michigan and U.S. dairy industry. Report 489. East Lansing: Michigan State University, Department of Agricultural Economics.

Hahn, D. E. 1983. Cost of bulk milk assembly. Proceedings of NE-126 Workshop, edited by Andrew M. Novakovic. Northeast Regional Research Publication 39. Ithaca, N.Y.: Cornell University Press. Hill, Arthur. 1989. Department of Food Science, University of Guelph. Personal Communication. Just, R. E., D. L. Hueth and A. Schmitz. 1982. Applied Welfare Economics and Public Policy. Englewood Cliffs, N.J.: Prentice-Hall.

Kay, R. D. 1986. Farm Management: Planning, Control, and Implementation. 2nd ed. New York: McGraw-Hill.

Leibman, J., L. Lasdon, L. Schrage and A. Waren. 1986. Modelling and Optimization with GINO. Palo Alto, Calif.: Scientific Press.

Losch, August. 1954. The Economics of Location. New Haven, Connecticut.

Lough, H. W. 1977. Truck Transportation Cost of Bulk Milk. Washington, D.C.: USDA, ERS. Morris, J. G., G. O. Wesolowsky and R. Love. 1988. Facilities Location: Models and Methods. New York: North Holland.
Mortara, F. A. 1986. Potential economic impacts of on-farm ultrafiltration on milk marketing. MSc thesis. Ithaca, New York: Cornell University. Norman, G. 1979. Economies of Scale, Transportation Costs, and Location. The Hague: Martinu Nijhoff Publishing.

Novakovic, A. M. and C. S. Alexander. 1987. The economic feasibility of ultrafiltration and thermalization of milk on Wisconsin farms. Ithaca, New York: Cornell University, Department of Agricultural Economics.

Ontario. Milk Marketing Board. 1989a. Dairy Statistical Handbook. Mississauga, Ont.: OMMB.

Ontario. Milk Marketing Board. 1989b. Ontario Milk Producer. Mississauga, Ont.: OMMB, February.

Ontario. Milk Marketing Board. 1991. Ontario Dain Farm Accounting Project. Mississauga. Ont.: OMMB.

Ontario. Ministry of Agriculture and Food. 1990. Ontario farm management accounting project 1989. Publication 69. Guelph: OMAF, Agricultural Representatives Branch.

Slack, A. W., C. H. Amundson and C. H. Hill. 1982. On-farm ultrafiltration of milk: Part 2 economic analysis. Process Biochemistry (September/October 1982): 23-33.

Stollsteimer, J. F. 1963. A working model for plant numbers and location. Journal of Farm Economics (August 1963): 631-45.

Stonehouse, Peter. 1979. Government policies for the Canadian dairy industry. Canadian Farm Economics: 1-11.

Weber, A. 1929. The Theory of the Location of Industries. Chicago: Chicago University Press. Zall, R. R. 1987. On-farm ultrafiltration of milk: The California experience. Journal of Nutrition Research and Food Science 42(1): 4-7.

\section{APPENDIX}

The partial budget presented in this study is based in part on Novakovic and Alexander (NA), Bretrand (B) Viguier (V), the Ontario Dairy Farm Accounting Project (ODFAP) (Ontario Milk Marketing Board), and the Ontario Farm Management Accounting Project (OFMAP) (Ontario Ministry of Agriculture and Food). The calculations and assumptions used are as follows:

1. Farm size is represented by the number of milking cows, ranging from 30 to 150 cows per farm. Average annual milk production per cow is $55.9 \mathrm{hL}$ ( $5756 \mathrm{~kg}$ ) (ODFAP).

2. The UF system evaluated in this study is the Alfa-Laval Thermicon, which continuously heats and concentrates milk at a flow rate equivalent to the speed of the milking system. with automatic adjustment to variations in the milk flow rate. The cost of the UF system 
(not installed, not including the thermalizer) is calculated as $\$ 11,100+(\$ 4,200 *$ number of membranes needed). The size and price of the thermalizer unit varies with herd size, with linear approximations for other herd sizes:

$\begin{array}{rc}\text { Cost } & \text { Herd size (cows) } \\ \$ 2,700 & 30 \\ 4,700 & 50 \\ 9,600 & 100 \\ \$ 14,500 & 200\end{array}$

Following NA and Alfa-Laval, installation costs and supplemental equipment is assumed to be $25 \%$ of the cost of the UF and thermalizer equipment.

3. Insurance, repair and maintenance on the UF system are set at $0.5 \%$ and $1.5 \%$ of the cost of the UF unit, respectively (based on ODFAP 1987). Alfa-Laval estimates parts and service on the UF unit to be $2 \%$ of the cost of the unit.

4. Membrane replacement costs are $\$ 800$ per year.

5. The concentration factor is $2 x$, which is a standard used in other studies (NA, B, V).

6. The UF membrane evaluated has an average capacity of 87.5 litres per hour.

7. Following NA, milking time is assumed to be two thirds a function of number of cows and one third a function of production per cow. Milking is assumed to take 12.5 minutes per cow ( 4.8 cows per hour) with an average milk flow of 2.65 litres per cow per minute (159 litres per hour). Total milking time is estimated as:

$$
M T=\left\{[(N C O W / 4.8 \text { cows/hour }) * 2 / 3]+\left[(M D A Y / 159 \mathrm{~L} / \mathrm{hour})^{*} 1 / 3\right]\right\} / M M U
$$

where

$\mathrm{MT}=$ milking time in hours per day

$N C O W=$ number of cows to be milked each day

$M D A Y=$ milk per day in litres

$M M U=$ number of milking machines units

$=3$ units for a herd of 30 to 50 cows

$=4$ units for a herd of 51 to 90 cows

$=5$ units for a herd of 91 cows or more.

Milk flow is calculated as Milk Flow (L/hour) = Milk per day (L/day) $/ M T$.

8. Transportation costs are $\$ 2.05 / \mathrm{hL}$, the average cost paid in southern Ontario (ODFAP).

9. The value of the permeate fed is based on a linear interpolation from Glover (1985), who calculated the values using Peterson's equations (Church 1986, 199-203):

$\begin{array}{cccccc}C F & \text { TS \% } & P \% & \text { NP-NC \% } & \text { Lactose \% } & \text { Ash \% } \\ 1 & 5.7 & 0.00 & 0.18 & 4.8 & 0.53 \\ 3 & 6.1 & 0.06 & 0.19 & 5.1 & 0.53\end{array}$

where

$$
\begin{aligned}
C F & =\text { concentration factor } \\
T S & =7 . \% \text { total solids, } \\
P & =\% \text { protein, } \\
N P-N C & =\text { nonprotein } n \text {-compounds. }
\end{aligned}
$$

To apply Peterson's equations, it is estimated that lactose and protein provide 4 Kilocalories per gram.

10. The basis feeds for comparison of the permeate value are corn and soybeans, which cost $\$ 150$ and $\$ 340$ per tonne, respectively. 
Table A-1. Estimation of the capital investment needed

\begin{tabular}{lccccccc}
\hline & \multicolumn{7}{c}{ Number of cows } \\
\cline { 2 - 7 } & 30 & 50 & 70 & 90 & 110 & 130 \\
\hline Milking time (hours/day) & 1.71 & 2.85 & 2.99 & 3.85 & 3.76 & 4.45 & 5.13 \\
Milk flow (L/hour) & 269 & 269 & 358 & 358 & 448 & 448 & 448 \\
Calculated \# of membranes needed & 1.84 & 1.84 & 2.46 & 2.46 & 3.07 & 3.07 & 3.07 \\
Actual number of membranes & 2.00 & 2.00 & 3.00 & 3.00 & 4.00 & 4.00 & 4.00 \\
Thermalizer cost (\$) & 2700 & 4700 & 6660 & 8620 & 10090 & 11070 & 12050 \\
Supplemental equipment (\$) & 5550 & 6050 & 7590 & 8080 & 9498 & 9743 & 9988 \\
UF and thermal unit (\$) & 22200 & 24200 & 30360 & 32360 & 37904 & 38970 & 39950 \\
Total investment cost (\$) & 27750 & 30250 & 37950 & 32320 & 47488 & 48713 & 49938 \\
UF depreciation (\$/year) & 2498 & 2723 & 3416 & 3636 & 4274 & 4384 & 4494 \\
Interest (\$/year) & 1832 & 1997 & 2505 & 2666 & 3134 & 3215 & 3296 \\
Total investment costs (\$/year) & 4329 & 4719 & 5920 & 6302 & 7408 & 7599 & 7790 \\
\hline
\end{tabular}

Table A-2. Estimation of operating cost

\begin{tabular}{lrrrrrrr}
\hline & \multicolumn{7}{c}{ Number of cows } \\
\cline { 2 - 7 } & \multicolumn{1}{c}{30} & \multicolumn{1}{c}{50} & 70 & \multicolumn{1}{c}{90} & 110 & 130 & 150 \\
\hline Membranes replaced (\$/year) & 1474 & 1474 & 1965 & 1965 & 2457 & 2457 & 2457 \\
Electricity (cleaning) \$/year & 66 & 110 & 155 & 199 & 243 & 287 & 331 \\
Electricity (UF) (\$/year) & 221 & 394 & 440 & 601 & 621 & 773 & 938 \\
Cleaning detergent (\$/year) & 211 & 352 & 493 & 634 & 775 & 916 & 1057 \\
Labor (\$/year) & 2005 & 2064 & 2124 & 2183 & 2242 & 2302 & 2361 \\
Ins., rep. and maint. (\$/year) & 444 & 484 & 607 & 646 & 760 & 779 & 799 \\
Total operating cost (\$/year) & 4422 & 4879 & 5784 & 6228 & 7097 & 7514 & 7943 \\
\hline
\end{tabular}


11. A linear depreciation of 10 years is assumed.

12. Interest is fixed at $12 \%$ per year.

13. Electricity costs and costs of cleaning the UF system follow B and V. Cleaning water per milking is estimated as $190 \mathrm{~L}$ hot water $+160 \mathrm{~L}$ cold water $+2.2 \mathrm{~L}$ rententate. Electricity (watts) for UF and thermization is estimated as Watts/L of milk $=1.14+$ $4539 / \mathrm{L}$ milk/day. Electricity to heat the cleaning water is Watts/hL/day $=5.2 *$ litres of hot water used per day. Electricity costs $\$ 0.07 / \mathrm{kW}$. Cost of cleaning detergent is $\$ 0.063 / \mathrm{hL} /$ day (Zall).

14. Labor required to operate the UF system (NA) is Total hours $=[45$ minutes +10 minutes $/ 220 \mathrm{hL}$ milk] $/ 60$.

15. Labor costs $\$ 7.00 /$ hour.

16. Electricity required to cool one hectolitre of milk is $1.814 \mathrm{kWh} / \mathrm{hL}$ (B). Savings realized from less milk to cool is estimated at $37.5 \%$ (NA, B, V). Hence, the savings per hectolitre from cooling UF milk is $1.814 \mathrm{kWh} / \mathrm{hL} * 0.375 *$ cost of electricity.

Table A-3. Costs and savings from using ultrafiltration at the farm, and results

\begin{tabular}{lrrrrrrrr}
\hline & \multicolumn{8}{c}{ Number of cows } \\
\cline { 2 - 9 } & \multicolumn{1}{c}{30} & 50 & 70 & 90 & 110 & 130 & 150 \\
\hline Cost of cooling milk in the tank (\$/hL) & 0.13 & 0.13 & 0.13 & 0.13 & 0.13 & 0.13 & 0.13 \\
Saving in cooling (\$/hL) & 0.05 & 0.05 & 0.05 & 0.05 & 0.05 & 0.05 & 0.05 \\
Total farm savings (\$/year) & 2187 & 3645 & 5103 & 6561 & 8019 & 9477 & 10935 \\
Farm net return (\$/year) & -6564 & -5953 & -6602 & -5970 & -6486 & -5636 & -4798 \\
Transportation savings (\$/year) & 1719 & 2865 & 4011 & 5157 & 6303 & 7449 & 8596 \\
Total net return (\$/year) & -4845 & -3088 & -2591 & -813 & -184 & 1813 & 3797 \\
\hline
\end{tabular}

